\title{
ANALISIS MINAT BELAJAR SISWA MTS KELAS VIII DALAM PEMBELAJARAN MATEMATIKA MELALUI APLIKASI GEOGEBRA
}

\author{
Akbar Hanipa $^{1}$, Abdul Robi Misbahudin ${ }^{2}$, Andreansyah $^{3}$, Wahyu Setiawan ${ }^{4}$ \\ 1,2,3,4 IKIP Siliwangi, Jl. Terusan Jenderal Sudirman, Cimahi, Jawa Barat, Indonesia \\ 19akbarhanipa@gmail.com, ${ }^{2}$ abdulrobi180@gmail.com, ${ }^{3}$ andreansyah@gmail.com, \\ 4kakwahyu3@gmail.com.
}

\begin{abstract}
This study was conducted to analyze the learning interest of class VIII MTs students in mathematical learning through Geogebra application. The research method used descriptive qualitative with a population of all MTs students in West Bandung Regency. The sample used was 28 students of class VIII-A MTs Al-Barry. The instrument used is the Learning Interest Scale with 20 statements that have positive and negative responses about learning using the Geogebra application. The learning interest scale is used to look for responses from respondents to the learning interest of junior / MTs students in statistical material whose learning uses Geogebra applications. The results of this study indicate that students' interest in learning in statistical material with Geogebra application media shows positive results with average responses showing a strong category with a percentage of $69,46 \%$. The average is obtained from data on each indicator of student learning interest.
\end{abstract}

Keywords: Geogebra, Interest in learning.

\begin{abstract}
Abstrak
Penelitian ini dilakukan untuk menganalisis minat belajar siswa MTs kelas VIII dalam pembelajaran matematika melalui aplikasi Geogebra. Metode penelitian menggunakan deskriptif kualitatif dengan populasi seluruh siswa MTs di Kabupaten Bandung Barat. Sampel yang di gunakan adalah siswa kelas VIII-A MTa Al-Barry sebanyak 28 orang siswa. Instrumen yang digunakan yaitu Skala Minat belajar dengan 20 pernyataan yang memiliki tanggapan positif dan negatif tentang pembelajaran menggunakan aplikasi Geogebra. Skala minat belajar digunakan untuk mencari tanggapan dari responden terhadap minat belajar dari siswa SMP/MTs pada materi statistika yang pembelajarannya menggunakan aplikasi Geogebra. Hasil dari penelitian ini menunjukan bahwa minat belajar siswa pada materi statistika dengan media aplikasi Geogebra menunjukan hasil yang positif dengan rataratarespon menunjukan kategori kuat dengan perolehan presentase $69,46 \%$. Rata-rata tersebut diperoleh dari data tiap indikator minat belajar siswa.
\end{abstract}

Kata Kunci: Geogebra, Minat belajar.

How to cite: Hanipa, A., Misbahudin, A. R., Andreansyah \& Setiawan, W. (2019). Analisis Minat Belajar Siswa MTs Kelas VIII Dalam Pembelajaran Matematika melalui Aplikasi Geogebra. JPMI - Jurnal Pembelajaran Matematika Inovatif, 2 (5), 315-322.

\section{PENDAHULUAN}

Pada dasarnya, pendidikan merupakan salah satu kebutuhan pokok setiap orang untuk meningkatkan pengembangan diri untuk kelangsungan hidupnya. Tanpa pendidikan manusia akan sulit berkembang dan terbelakang. Selain itu juga melahirkan generasi-generasi penerus yang berkualitas. Hal ini sejalan dengan dengan pendapat (Barnadib, 1994) pendidikan yaitu usaha seseorang secara sadar dan sistematis untuk mencapai taraf hidup yang lebih baik lagi. Adapun tujuan pendidikan menurut undang-undang No. 20 Tahun 2003 (Depdiknas \& No, 2003) bahwa pendidikan merupakan suatu usaha yang dilakukan dengan sadar dan terencanan 
yaitu untuk mewujudkan suatu proses pembelajaran, dengan demikian peserta didik dapat mengembangkan potensi dirinya agar memiliki kecerdasan spiritual, akhlak mulia, pengendalian diri, kepribadian, kecerdasan, serta keterampilan yang dia butuhkan untuk dirinya sendiri, lingkungan masyarakat, bangsa dan negara. Melihat pentingnya pendidikan untuk masa depan bangsa, maka mutu pendidikan perlu untuk ditingkatkan oleh sekolah khususnya mutu pendidikan matematika yang yang merupakan landasan dan kerangka pembangunan suatu ilmu pengetahuan dan teknologi.

Setiawan (2015) mengungkapkan agar kualitas pendidikan dapat ditingkatkan maka sekolah perlu untuk menyiapkan peserta didik sehingga berbagai macam kemampuan dapat dimilikinya, juga peserta didik memiliki kualitas dalam bersaing. Untuk itu banyak hal yang perlu dilakukan demi tercapainya keberhasilan dalam pembelajaran. Sikap siswa dalam mengikuti pembelajaran tergantung bagaimana cara guru memberikan pembelajaran. Setiap proses pembelajaran tentunya mengharapkan siswa memperoleh hasil belajar yang baik. Namun kenyatanyaan nya hasil belajar siswa tidak selalu baik dan sesuai harapan. Hal ini biasanya terjadi apabila siswa merasa tidak tertarik mengikuti pembelajaran karena matematika dianggap sulit dan membosankan. Menurut penelitian Siregar (2017), persepsi siswa mengenai pembelajaran matematikadidapatkan hasil $45 \%$ yang mengatakan bahwa mata pelajaran matematikaitu sangat sulit. Kemudian menurut Marfuah (Rahmawati, Bungsu, Islamiah, \& Setiawan, 2019) Matematika merupakan pembelajaran yang kurang diminati oleh siswa.

Dalam belajar mengajar tidak akan bisa terlepas dari pemanfaatan media pembelajaran serta bahan ajar. Bahan ajar sangat penting bagi guru maupun siswa. Guru akan sangat kesulitan untuk meningkatkan kualitas dalam belajar mengajar jika tidak disertai bahan ajar yang baik. Begitupun juga dengan siswa, jika tidak ada bahan ajar siswa akan sangat kesulitan dalam proses belajarnya, jika guru kurang jelas dan terlalu cepat dalam menjelaskan materi pembelajarannya hal ini akan menambah kesulitan guru dalam memahamkan siswa, sehingga siswa tidak memberi respon yang baik saat belajar dan perhatian siswa selama belajar berkurang. Oleh karena itu upaya meningkatkan kualitas dan kuantitas kegiatan belajar mengajar, bahan ajar sangat penting untuk dikembangkan, pada dasarnya bahan ajar sendiri memiliki peranan penting baik bagi guru, siswa dan kegiatan belajar mengajar.

Menurut Asnawir \& Usman (2002) dalam penggunaannya media pembelajaran memiliki fungsi antara lain: 1) Membantu belajar bagi siswa dan membantu mengajar bagi guru. 2) Pengalaman lebih nyata bagi siswa (dari abstrak menjadi lebih konkrit). 3) Menarik perhatian siswa (kegiatan pembelajaran lebih menyenangkan juga tidak membosankan). 4) Mengaktifkan semua indra yang dimiliki siswa. 5) Menarik perhatian dan minat siswa dalam belajar. Dari paparan diatas dapat disimpulkan, manfaat penggunaan media pembelajaran pada proses belajar mengajar dapat memfokuskan perhatian siswa sehingga materi yang dajarkan akan lebih jelas juga mudah dipahami, dengan demikian akan timbul motivasi untuk belajar yang pada akhirnya prestasi siswa dapat meningkat.

Minat belajar merupakan suatu kegiatan yang dilakukan oleh seseorang dalam proses pembelajaran secara tetap dengan perasaan senang tanpa adanya paksaan oleh orang lain (Rojabiyah \& Setiawan, 2019). Minat belajar siswa sangat berpengaruh terhadap hasil belajar siswa.Sejalan dengan pemaparan hasil penelitian minat belajar menurut Rahmawati et al. (2019) kebiasaan dan minat dalam belajar sangat berpengaruh terhadap prestasi belajar siswa secara signifikan karena semakin tinggi minat belajar maka semakin tinggi pula prestasi 
belajar yang diperolehnya. Segala bentuk yang membuat kita ingin melakukan sesuatu terhadapnya atau menarik perhatian kita biasa disebut dengan minat.

Menurut Slameto (2003) minat adalah susatu rasa lebih menyukai sesuatu dan rasa ketertarikan pada suatu hal atau aktivitas berdasarkan kesadaran diri sendiri. Maka dari itu minat belajar siswa sangat penting untuk di kembangkan pada diri siswa agar memiliki kesadaran pada diri sendiri untuk belajar dan mencapai hasil yang di inginkan. Adapun indikator minat belajar berdasarkan Brown (Hendriana, Rohaeti, \& Sumarmo, 2017), (Islamiah, 2019) diantanya adalah: (a) Perasaan senang; (b) Adanya rasa ketertarikan; (c) Keterlibatan dalam belajar; (d) Rajin belajar dan mengerjakan tugas; (e) Tekun dan disiplin dalam belajar; serta memiliki (f) jadwal belajar.

Menurut Slameto (2003) ciri-ciri siwa yang memiliki minat untuk belajar sebagai berikut : 1) selalu memperhatika dan akan berusaha mengingat segala sesuatu yang dipelajarinya secara continue. 2) memiliki perasaan senang dan suka dengan apa yang diminatinya. 3) adanya rasa kebanggaan tersendiri serta kepuasan batin terhadap apa yang diminati. 4) Minatnya lebih besar kepada hal-hal yang dia sukai ketimbang hal yang lain 5) diwujudkan dengan ikutserta pada aktivitas dan kegiatan. Adapun indikator minat belajar menurut Slameto (2003) yaitu: perasaan senang, ketertarikan, penerimaan, dan keterlibatan siswa.

Dari beberapa definisi juga indikator minat belajar yang dikemukakan diatas maka peneliti menmilih menggunakan indikator minat belajar, yaitu: a) Perasaan Senang, siswa tidak akan merasa terpaksa untuk mengikuti kegiatan belajar mengajar apabila siswa memiliki perasaan senang terhadap apa yang dipelajarinya. Contohnya antara lain, senang mengikuti kegiatan belajar mengajar, tidak merasa bosan, dan selalu hadir saat pelajaran tersebut. b) Keterlibatan Siswa, ketertarikan seseorang terhadap obyek sehingga orang tersebut tertarik untuk melakukan hal yang sama dengan objek tersebut. Contohnya giat bekerjasama saat berdiskusi, selalu bertanya ketika ada yang tidak dimengertisemangat dan aktif menjawab setiap pertanyaan dari guru. c) Ketertarikan, berhubungan dengan adanya factor pendorong siswa terhadap ketertarikan pada suatu benda, orang, serta kegiatan berupa pengalaman yang dirangsang oleh kegiatan itu sendiri. Contohnya semangat dan antusias ketika mengikuti kegiatan belajar mengajar, tidak menunda-nunda tugas dari guru. d) Perhatian Siswa, minat dan perhatian dalam penggunaannya adalah dua hal bisa dianggap sama, perhatian yaitu konsentrasi siswa dalam mengamati segala sesuatu yang disukai. Apabila siswa memiliki minat pada suatu obyek tertentu maka siswa tersebut akan memperhatikan terus obyek tersebut. Contohnya siswa akan setia mendengarkan penjelasan guru dan mencatat materi yang disampaikan oleh guru.

Menurut Nopiyanti (2012) Media dengan menggunakan TIK dapat membantu guru memvisualisasikan konsep abstrak menjadi konkrit dan mampu membuat siswa menjadi lebih aktif. Oleh karena itu media TIK sangat bermanfaat sekali dalam proses pembelajaran. Selain itu waktu yang digunakan dalam pemanfaatan media pembelajaran sangat efektif, kita tidak lagi harus menuliskan sebuah materi di papan tulis. Media TIK juga memberikan akses lebih mudah untuk menggali informasi yang ingin didapat. Media TIK yang dibuat seperti LKS yang berisi penyajian materi secara ringkas serta kegiatan yang menuntut siswa lebih aktif seperti diskusi, latihan soal, dan mind/hand activity sangat baik untuk meningkatkan minat siswa dalam mempelajari mata pelajaran matematika dan mengembangkan keterampilan proses (Setiawan \& Sari, 2018).

Dengan diterapkannya minat belajar siswa akan menjadi lebih tertarik terhadap apa yang akan dipelajarinya. Selain itu minat belajar juga menjadi faktor penunjang keberhasilan siswa 
dalam melakukan kegiatan, oleh karena itu minat belajar perlu mendapat perhatian khusus dari guru atau orang tua untuk memudahkan dalam membimbing dan mengarahkan anak dalam belajar. Dari beberapa uraian diatas dapat disimpulkan bahwa minat belajar merupakan ketertarikan pada sesuatu yang relatif tetap sehingga mengingat juga memperhatikan sesuatu secara berkelanjutan yang diikuti rasa senang untuk memperoleh suatu kepuasaan dalam mencapai tujuan pembelajaran. Berdasarkan latar belakang, hal yang ingin diuraikan dalam penelitian ini yaitu untuk mendeskripsikan analisis minat belajar siswa SMP MTs kelas VIII dalam pembelajaran matematika dengan menggunakan aplikasi.

\section{METODE}

Metode penelitian ini adalah deskriptif kualitatif. Penelitian ini dilaksanakan pada siswa kelas VIII-A pada semester ganjil tahun ajaran 2018-2019 di MTs Al-Barry Cikalongwetan dengan jumlah siswa 28 orang. Peneliti memberikan angket yang berisi 20 pernyataan positif dan negatif untuk mengukur kemampuan afektif siswa pada saat belajar yaitu pada kemampuan afektif minat belajar siswa.

Teknik pengolahan data yang dipakai peneliti adalah dengan menggunakan Microsoft excel. Data skala sikap yang tadinya memiliki nilai ordinal diubah kedalam bentuk nilai interval menggunakan bantuan Method of Succesive Interval (MSI) oleh Microsoft excel. Teknik ini merupakan langkah dalam mengolah skala sikap yaitu seperangkat pernyataan dengan jawaban yang disediakan dan dipilih oleh responden. Penskoran yang digunakan menggunakan skala likert yang telah dimodifikasi yaitu: sangat setuju (SS), Setuju (S), tidak setuju (TS), dan sangat tidak setuju (STS). Adapun point dari setiap skala sebagai berikut:

Tabel 1

Point Skala Sikap Minat Belajar

\begin{tabular}{llcc}
\hline \multirow{2}{*}{ No. } & \multicolumn{1}{c}{ Skala } & \multicolumn{2}{c}{ Point } \\
\cline { 3 - 4 } & & Positif & Negatif \\
\hline 1. & Sangat Setuju (SS) & 4 & 1 \\
2. & Setuju (S) & 3 & 2 \\
3. & Tidak Setuju (TS) & 2 & 3 \\
4. & Sangat Tidak Setuju (STS) & 1 & 4 \\
\hline
\end{tabular}

Skala sikap minat belajar digunakan untuk mencari tanggapan dari responden terhadap minat belajar dari siswa SMP/MTs kelas VIII dalam pembelajaran matematikadengan menggunakan aplikasi Geogebra. Data yang telah di dapat untuk dijadikan hasil penelitian sehingga dapat ditarik kesimpulan. Kemudian hasil dari penelitian tersebut di klasifikasikan berdasarkan kriteria presentase skala menurut (Riduwan, 2007)

Tabel 2

Kriteria Spesifikasi Skala Sikap

\begin{tabular}{cl}
\hline Kriteria $(\%)$ & Klasifikasi \\
\hline $0 \leq \mathrm{NA} \leq 20$ & Sangat Lemah \\
$20 \leq \mathrm{NA} \leq 40$ & Lemah \\
$40 \leq \mathrm{NA} \leq 60$ & Cukup \\
$60 \leq \mathrm{NA} \leq 80$ & Kuat \\
$80 \leq \mathrm{NA} \leq 100$ & Sangat Kuat \\
\hline
\end{tabular}




\section{HASIL DAN PEMBAHASAN}

\section{Hasil}

Hasil penelitian ini adalah pengumpulan data skala sikap minat belajar dari responden siswa setelah diberikan materi staistika dengan menggunakan aplikasi Geogebra. Adapun kegiatan yang dilakukan pada saat pembelajaran adalah sebagai berikut:

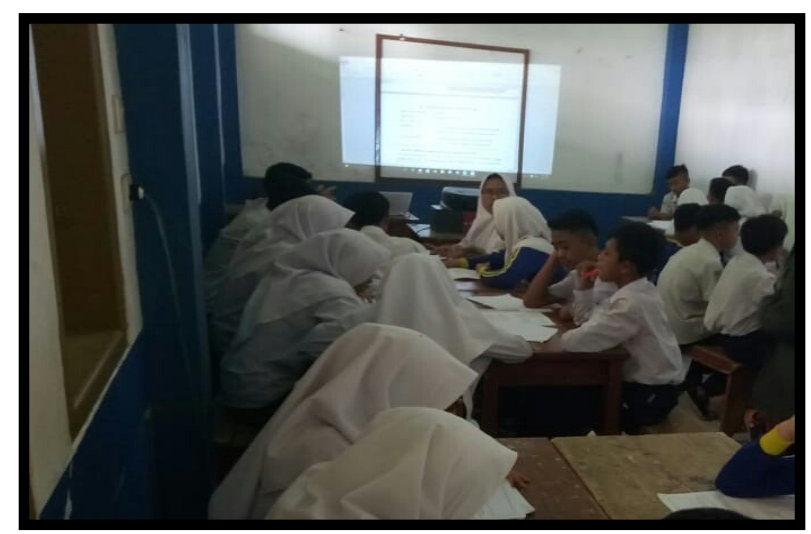

Gambar 1 Siswa sedang diberikan materi dengan aplikasi geogebra

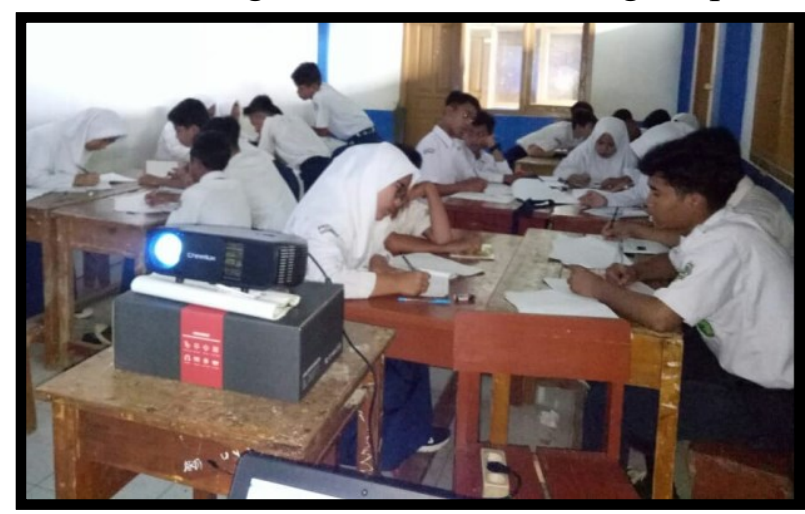

Gambar 2 Siswa sedang mengisi angket Minat belajar siswa

Setelah melakukan pembelajaran materi statistika dengan aplikasi Geogebra di MTs Al-Barry kelas VIII-A dengan banyak siswa 28 orang sebagai responden. Maka selanjutnya peneliti melakukan analisis skala minat belajar yang terdiri dari 20 pertanyaan yang meliputi pertanyaan positif dan pertanyaan negatif. Selanjutnya hasil data yang diperoleh dari hasil skala minat belajar dapat dilihat pada tabel berikut ini :

Tabel 3

Presentase Skala Sikap Minat Belajar

\begin{tabular}{|c|c|c|c|c|c|c|}
\hline \multirow{2}{*}{ No } & \multirow{2}{*}{ Indikator } & \multirow{2}{*}{$\begin{array}{l}\text { Banyak } \\
\text { pernyataan }\end{array}$} & \multicolumn{3}{|c|}{ Total } & \multirow{2}{*}{ Kategori } \\
\hline & & & Skor & Mean & $\%$ & \\
\hline 1 & Perasaan senang & 6 & 384 & 16,79 & 69,94 & Kuat \\
\hline 2 & Ketertarikan siswa & 3 & 248 & 8,86 & 73,81 & Kuat \\
\hline 3 & Keterlibatan siswa & 4 & 298 & 10,64 & 66,52 & Kuat \\
\hline 4 & $\begin{array}{l}\text { Rajin dalam } \\
\text { belajar }\end{array}$ & 3 & 238 & 8,50 & 70,83 & Kuat \\
\hline 5 & $\begin{array}{l}\text { Tekun dalam } \\
\text { belajar dan } \\
\text { disiplin }\end{array}$ & 4 & 302 & 10,79 & 67,41 & Kuat \\
\hline & Total & 20 & 1564 & 55,57 & 69,46 & Kuat \\
\hline
\end{tabular}


Dari tabel 4 dapat kita lihat bahwa rata-rata perolehan presentase tiap indikator dengan presentase $69,46 \%$ masuk kedalam kategori kuat. Berikut deskriptif statistik visual data minat belajar siswa :

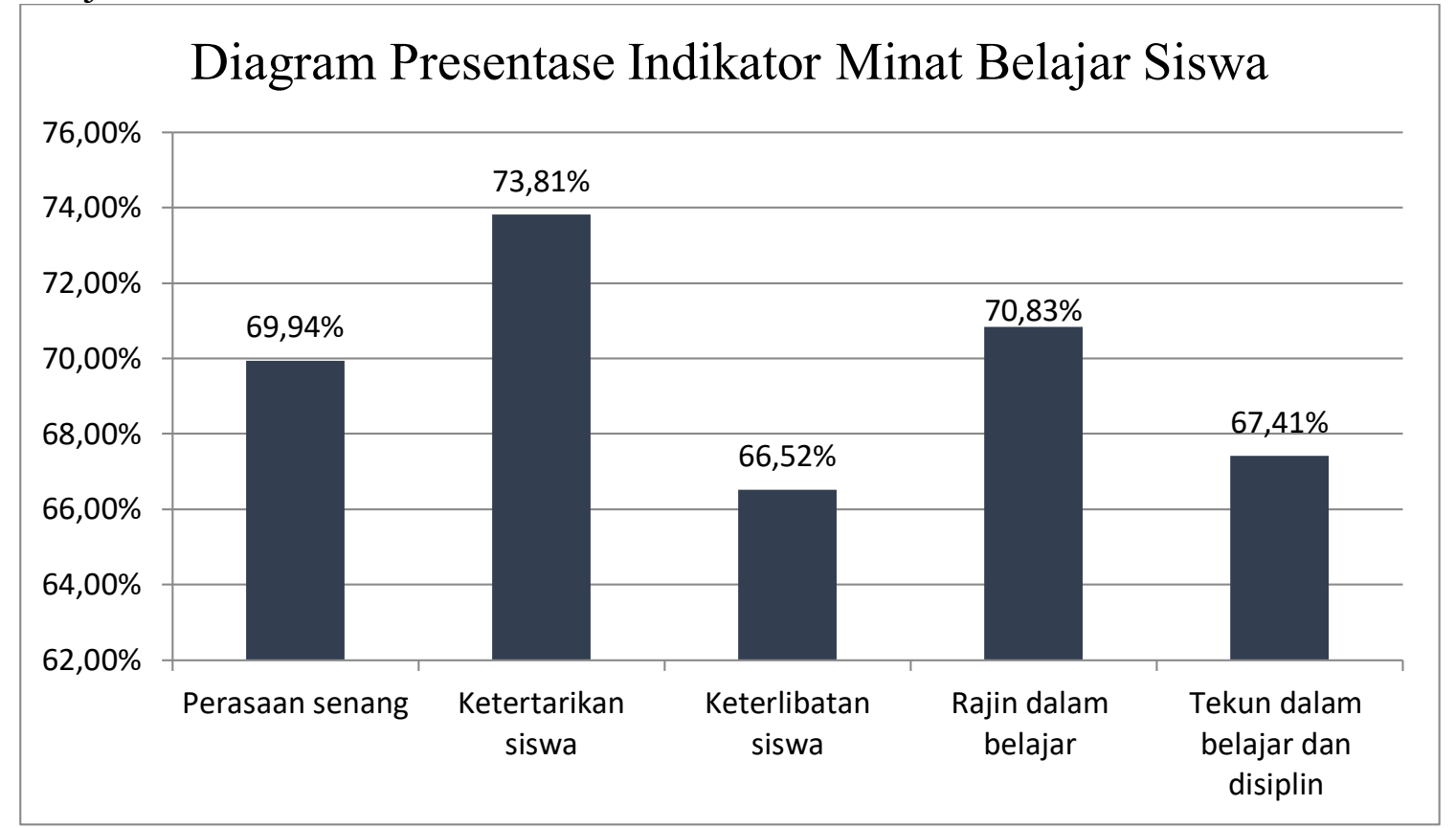

Gambar 3. Diagram Persentase Indikator Minat Belajar Siswa

Dilihat dari gambar 3 diagram persentase indikator pada minat belajar siswa untuk indikator perasaan senang memperoleh presentase 69,94\%, untuk indikator ketertarikan siswa mendapatkan presentase yang paling unggul dari indikator lainnya dengan perolehan presentase $73,81 \%$. Selain itu untuk indikator keterlibatan siswa memperoleh presentase sebesar $66,52 \%$. Serta indikator rajin dalam belajar dengan presentase $70,83 \%$ dan yang terakhir untuk indikator tekun belajar dan disiplin memperoleh presentase $67,41 \%$.

\section{Pembahasan}

Dari data diatas terlihat bahwa rata-rata respon siswa MTs dengan pembelajaran menggunakan aplikasi Geogebra memperoleh respon positif pada setiap indikator minat belajar, hal tersebut dibuktikan dengan hasil persentase setiap indikator dengan kategori kuat. Indikator perasaan senang memperoleh persentase $69,44 \%$ hal tersebut dikarenakan pembelajaran menggunakan aplikasi Geogebra merupakan pembelajaran yang dianggap baru oleh siswa, sehingga siswa terlihat gembira selama pembelajaran berlangsung. Artinya, siswa merasa senang saat kegiatan belajar mengajar menggunakan aplikasi Geogebra hal ini sejalan dengan penelitian Subekti \& Kusuma (2015) yang menyatan bahwa siswa terlihat senang mencoba hal-hal yang baru. Mereka terlihat antusias menyelesaikan permasalahan menggunakan aplikasi Geogebra. Selain itu rasa percaya diri mereka selama pembelajaran juga semakin baik

Pada indikator ketertarikan siswa, hasil persentase adalah 73,81\% dimana pada indikator ini memperoleh hasil persentase paling tinggi dibanding indikator-indikator lain, hal ini bisa terjadi dikarenakan media visual dapat menjadikan pembelajaran lebih menarik sehingga hampir semua siswa merasa tertarik dengan apa yang di sajikan oleh peneliti. Hal tersebut sejalan dengan Ariawan (2015) yang menyatakan bahwa dengan menggunakan aplikasi Geogebra siswa menjadi lebih tertarik mengikuti pembelajaran, bahkan dari awal sampai akhir pembelajaran. Siswa lebih fokus dan lebih tertarik dengan berbagai kelebihan media komputer karena mampu menampilkan animasi dan warna yang jauh lebih menarik 
Pada indikator keterlibatan siswa, memperoleh persentase 66,52\%. Pada saat di lapangan siswa berani mencoba menggunakan aplikasi Geogebra dengan mempraktekannya di depan kelas. Bahkan beberapa siswa mencoba mempraktekannya di rumah menggunakan aplikasi Geogebra versi Android. Sehingga keterlibatan siswa terhadap aplikasi Geogebra sangat tinggi. hal ini sejalan dengan Nopiyanti (2012) yang menyatakan bahwa dengan adanya aplikasi Geogebra memberikan dampak positif terhadap meningkatnya keterlibatan siswa dalam pembelajaran terlihat adanya interaksi siswa dengan siswa dan siswa dengan guru serta rasa tanggung jawab siswa terhadap pembelajaran yang sedang dilaksanakan.

Pada indikator rajin dalam belajar, memperoleh persentase $70,83 \%$ hal ini dibuktikan oleh tingkat pemahaman siswa setelah mengikuti kegiatan belajar mengajar dengan aplikasi geogebra menjadi lebih meningkat serta siswa menjadi bersemangat dalam belajar sehingga siswa menjadi lebih rajin dalam belajar. hal ini sejalan dengan hasil penelitian (Rahmawati et al., 2019) yang menyatakan bahwa minat belajar siswa yang pembelajaran nya menggunakan aplikasi Geogebra pada indikator rajin dalam belajar terjadi peningkatana kualitas belajar yang signifikan.

Pada indikator tekun dalam belajar dan disiplin memperoleh persentase $67,41 \%$ hal tersebut terbukti pada saat pembelajaran, siswa terlihat lebih tekun dan disiplin siswa lebih fokus dengan media visual yang disajikan serta situasi pembelajaran yang kondusif membuat kenyamanan tersendiri terutama untuk siswa yang sedanga memperhatikan pelajaran. Hal tersebut sejalan dengan Putri, Hasnita, Vilardi, \& Setiawan (2019) yang menyatakan bahwa minat belajar siswa pada indikator tekun dalam belajar dan disiplin terjadi peningkatan yang signifikan

Berdasarkan hasil persentase minat belajar siswa menunjukan respon positif bisa berpengaruh terhadap hasil belajarnya. Pencapaian siswa dalam suatu mata pelajaran, bergantung pada minat belajar (Siagian, 2015). Jika hasil belajar baik karena minat belajar yang kuat berarti pemahaman siswa tentang pembelajaran pun baik. Oleh karena itu dapat kita simpulkan bahwa pembelajaran dengan menggunakan aplikasi Geogebra memberikan dampak positif pada minat belajar yang berpengaruh terhadap hasil belajar siswa dan dapat dikatakan bahwa pemahaman siswa mengenai materi statistika juga baik. Hal ini juga dipaparkan oleh hasil penelitian menurut Rohaeti \& Bernard (2018) Pemahaman siswa yang pembelajaran menggunakan media Geogebra menujunjukan hasil yang lebih baik dari pembelajaran biasa, serta peningkatan dalam pembelajaranpun lebih baik dari pembelajaran biasa.

\section{KESIMPULAN}

Dari hasil analisis data berdasarkan yang sudah di paparkan diatas dapat disimpulkan bahwa pembelajaran pada siswa kelas VIII-A MTs Al-Barry yang pembelajarannya menggunakan media aplikasi Geogebra mendapatkan respon yang positif dimana rata-rata siswa memiliki indikator minat belajar yang kuat. Pengalaman baru yang didapatkan siswa dengan pembelajar berbasis ICT menggunakan aplikasi Geogebra menjadikan siswa memiliki rasa ingin tahu lebih dan itu menimbulkan kesenang tersendiri bagi siswa. Perasaan senang tersebut juga mendorong siswa untuk aktif dan terlibat dalam pembelajaran bukan hanya mendengarkan penjelasan tapi siswa juga ikut mencoba merasakan hal yang baru mereka dapatkan. Hal tersebut yang menjadi faktor siswa memiliki minat belajar yang baik.

Untuk peneliti yang akan datang, diharapkan dapat mengembangkan hasil penelitian ini dalam lingkup yang lebih luas. Kemudian menambah wawasan dan meningkatkan kualitas pembelajaran, khususnya pembelajaran matematika dengan menggunakan aplikasi Geogebra. 


\section{UCAPAN TERIMA KASIH}

Penulis mengucapkan terimakasih kepada pihak yang terkait demi kelangsungan penelitian ini. Termasuk didalamnya Wahyu Setiawan, M.Pd dan Usman Aripin, M.Pd. karena dukungan dan bimbingannya dalam menyelesaikan penelitian ini. Tak lupa kepada pihak MTs yang dijadikan tempat berlangsungnya penelitian.

\section{DAFTAR PUSTAKA}

Ariawan, B. (2015). Menyelesaikan Permasalahan Program Linear Menggunakan Geogebra. Prosiding Seminar Nasional Teknologi Pendidikan, 69-85.

Asnawir, B. U., \& Usman, M. B. (2002). Media pembelajaran. Jakarta: Ciputat Pers.

Barnadib, I. (1994). Filsafat Pendidikan: Sistem dan Metode. Yogyakarta, Andi Ofset.

Depdiknas, U.-U. R. I. N., \& No, R. I. (2003). Tahun 2003 tentang sistem pendidikan nasional. Jakarta: Dirjen Pendidikan Dasar Dan Menengah.

Hendriana, H., Rohaeti, E. E., \& Sumarmo, U. (2017). Hard skills dan soft skills matematik siswa. Bandung: Refika Aditama.

Islamiah, I. D. (2019). Pengaruh Minat Belajar Siswa Terhadap Prestasi Belajar Matematika Di SMKN 1 Cihampelas. Journal on Education, 1(2), 451-457.

Nopiyanti, N. L. P. A. (2012). Pengembangan Perangkat Pembelajaran Geometri Berbantuan Geogebra dalam Upaya Meningkatkan Keterlibatan dan Prestasi Belajar Matematika Siswa Kelas VII. Jurnal Pendidikan Dan Pembelajaran Matematika Indonesia, 1(2).

Putri, A. D., Hasnita, S., Vilardi, M., \& Setiawan, W. (2019). Analisis Pengaruh Minat Belajar Siswa MA Dengan Menggunakan Aplikasi Geogebra Pada Materi SPLDV. Edumatica: Jurnal Pendidikan Matematika, 9(1), 47-52.

Rahmawati, N. S., Bungsu, T. K., Islamiah, I. D., \& Setiawan, W. (2019). Analisis Minat Belajar Siswa Ma Al-Mubarok Melalui Pendekatan Saintifik Berbantuan Aplikasi Geogebra Pada Materi Statistika Dasar. Journal on Education, 1(3), 386-395.

Riduwan, M. B. A. (2007). Skala pengukuran variabel-variabel penelitian. Alf. Bandung.

Rohaeti, E. E., \& Bernard, M. (2018). THE STUDENTS'MATHEMATICAL UNDERSTANDING ABILITY THROUGH SCIENTIFIC-ASSISTED APPROACH OF GEOGEBRA SOFTWARE. Infinity Journal, 7(2), 165-172.

Rojabiyah, A. B., \& Setiawan, W. (2019). Analisis Minat Belajar Siswa MTs Kelas VII dalam Pembelajaran Matematik Materi Aljabar Berdasarkan Gender. Journal on Education, $1(2), 458-463$.

Setiawan, W. (2015). Meningkatkan kemampuan berpikir kritis matematis siswa SMP dengan menggunakan model penemuan terbimbing. P2M STKIP Siliwangi, 2(1), 91-97.

Setiawan, W., \& Sari, V. T. A. (2018). Pengembangan Bahan Ajar Konsep Diferensial Berbasis Konflik Kognitif. Jurnal Elemen, 4(2), 204-215.

Siagian, R. E. F. (2015). Pengaruh minat dan kebiasaan belajar siswa terrhadap prestasi belajar matematika. Formatif: Jurnal Ilmiah Pendidikan MIPA, 2(2).

Siregar, N. R. (2017). Persepsi siswa pada pelajaran matematika: studi pendahuluan pada siswa yang menyenangi game. Prosiding Temu Ilmiah Nasional X Ikatan Psikologi Perkembangan Indonesia, 1.

Slameto, B. D. F.-F. Y. (2003). Mempengaruhinya. Jakarta: Rineka Cipta.

Subekti, F. E., \& Kusuma, A. B. (2015). Efektivitas Problem Based Learning Berbantuan Software Geogebra pada Geometri Transformasi. Seminar Nasional Matematika dan Pendidikan Matematika UNY. 